\title{
The Effect of Property Rights on the Relationship Between Economic Growth and Pollution for Transition Economies
}

\section{Ebru Guven Solakoglu}

To cite this article: Ebru Guven Solakoglu (2007) The Effect of Property Rights on the Relationship Between Economic Growth and Pollution for Transition Economies, Eastern European Economics, 45:1, 77-94

To link to this article: http://dx.doi.org/10.2753/EEE0012-8775450104

曲 Published online: 08 Dec 2014.

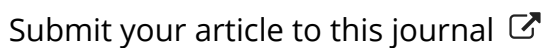

Џlll Article views: 19

Q View related articles 지

4 Citing articles: 2 View citing articles 
Eastern European Economics, vol. 45, no. 1, January-February 2007, pp. 77-94.

(C) 2007 M.E. Sharpe, Inc. All rights reserved.

ISSN 0012-8775/2007 \$9.50+0.00.

DOI 10.2753/EEE0012-8775450104

\author{
Ebru Guven Solakoglu
}

\title{
The Effect of Property Rights on the Relationship Between Economic Growth and Pollution for Transition Economies
}

\begin{abstract}
The paper measures changes in environmental quality in transition countries from 1987 to 2000 because of economic growth and environmental reforms. Indication of property rights may accelerate the growth process, as well as the composition effect on the environment. Thus, we compare transition countries that are not yet members of the European Union offering poorly defined property rights with EU-member transition countries offering better-defined property rights. We find that although EU-member transition countries exhibit an inverted $U$-shaped relationship between pollution intensity and economic growth, with a turning point at $\$ 5,710$, non EU-member transition countries do not support such a relation.
\end{abstract}

The investigation of an inverted U-shaped relation between economic development and pollution started with Lucas et al. (1992) and Grossman and Krueger $(1993 ; 1995)$. Many other studies followed; they differed in the type of pollutant examined, such as sulfhur dioxide $\left(\mathrm{SO}_{2}\right)$, nitrogen oxides $\left(\mathrm{NO}_{\mathrm{x}}\right)$, total suspended particulate (TSP), and carbon, but most supported an inverted U-shaped relation between economic development and pollution. However, their results indicated different turning

Ebru Guven Solakoglu is an assistant professor in the Banking and Finance Department, Bilkent University, Turkey. The author thanks H. Hettige and D. Shamon for providing the IPPS database, Tomislav Vukina and John Beghin for their contributions, and M. Nihat Solakoglu for his valuable comments. 
points, mostly due to differences in their model specifications (HoltzEakin and Selden 1995; Roberts and Grimes 1997; Selden and Song 1994; Shafik and Bandyopadhyay 1992).

Later studies expanded earlier studies by including other pollutants, such as automobile emissions (Kahn 1998) and toxic waste (Arora and Cason 1999; Millimet and Stengos 1999; Wang et al. 1998). Most of these studies agreed that economic growth does not steadily deteriorate environmental quality. In general, they concluded that the relation between income and the demand for environmental quality is likely to depend on the type of measure used to represent environmental quality. There were also theoretical derivations of the relationship (Andreoni and Levinson 2001; Selden and Song 1994). In addition, some studies introduced factors such as trade and openness to explain the relation between environment and economic growth (Frankel and Rose 2002; Vukina et al. 1999).

Frankel and Rose (2002) analyzed the effect of trade on a country's environment for a given level of gross domestic product (GDP), and concluded that the results generally support the inverted U-shaped relation of environment and growth, as well as the proposition that openness to trade accelerates the growth process. Vukina et al. (1999) measured changes in environmental quality in the early years of economic transition for twelve Central and East European (CEE) countries and newly independent states (NISs) by separating the pollution into scale and composition effects. They found that emissions from manufacturing output have decreased because of a substantial fall in the manufacturing output of transition countries. However, emissions due to the composition effect had heterogeneous patterns. ${ }^{1}$

Transition economies are an interesting sample to use to investigate the relation between environmental quality and economic growth. Environmental issues were not a priority in the command systems, and heavy goods production encouraged environmental degradation. However, in the move away from command economies toward market-driven economies in the first half of the 1990s, liberalized prices led to inflation and loss of macroeconomic control. Furthermore, due to economic turmoil and the beginning of competition in the early phases of transition, profits and output fell sharply, leading to decreases in pollution levels. ${ }^{2}$ The output fall came from both supply and demand factors. In contrast to some countries in the Commonwealth of Independent States (CIS), East European and Baltic states showed smaller output falls and faster recoveries. ${ }^{3}$ 
After the mid-1990s, however, macroeconomic stability showed a mixed picture. Output started growing rapidly mostly in the Baltic countries, but it was slower in others. Most of the growth was partly from increases in domestic demand (e.g., Hungary, Slovenia, Lithuania, Estonia) and partly from increases in external demand (e.g., Hungary, Slovak Republic, Lithuania). Some investments were made in the environment to reduce emissions after the mid-1990s as a result of increases in household incomes and preparation for EU environmental standards. ${ }^{4}$

This paper examines the effect of reforms on environmental quality for transition economies from 1987 to 2000 . It focuses on the effect of the existence of property rights on environmental quality and economic growth by investigating whether the indication of property rights accelerates the growth process and provides better environmental quality. That is, do countries with better-defined property rights reach a cleaner environment sooner than do other transition countries? We address this question by comparing two groups of transition economies: new EU-member countries with better-established property rights, and the rest of the transition countries with poorly established property rights.

We hypothesize that legal protection of property rights creates incentives to use resources efficiently, and the efficient use of resources may lead to better environmental quality. We assume that EU membership for the eight transition countries required better-defined property rights compared to the rest of the transition countries. However, the definitions of the measures that define property rights are not explicit, as the measures are debatable to capture the essence of property rights. Previous studies (e.g., Deacon 1994; Pargal and Wheeler 1996) consider different definitions of measures that explain the degrees of property rights in different countries. Some examples for definitions of property rights are measures of political turmoil and repression (Deacon 1994), land tenure, land values, identity of the land agencies involved and investment (Alston et al. 1996), and exchange controls and the ratio of total credit allocated to the private sector as a percentage of GDP (Leblang 1996). The existence of property rights and their effect on resource use, investment, and market expansion has become an important issue explaining differences in economic growth (Leblang 1996; Scully 1992). ${ }^{5}$ Furthermore, differences in economic growth across countries may explain changes in environmental quality (Barzel 1989). ${ }^{6}$ This study does not incorporate any definitions of property rights into the analysis; rather, 
it captures the effect of property rights in a comparative study by assuming that being a EU-member state indicates better-defined property rights for those countries.

The assumption that EU member states have stronger property rights is relevant because democratic nations tend to protect property rights more than do nondemocratic nations (Leblang 1996), and democratization is an outright pressure from international organizations. The European Union required democracy as an explicit precondition for accession negotiations (Fidrmuc 2003). To test our assumption, we use the ratio of total credit allocated to the private sector as a percentage of GDP to indicate property rights, following Leblang (1996). Although the ratio is not the only indicator, it was used in previous studies and was available for our sample. The latest data available was for 2002, and with the exception of Lithuania, the measure almost ranked countries by their EU membership. For EU transition countries, the ratio of total credits allocated to the private sector is much higher than it is for non-EU transition countries. While the ratio changes from 28.8 to 40.6 for EU transition countries in 2002, for non-EU transition countries, it changes from 4.2 to 18.8. Thus, it is possible to depend on EU membership to define property rights for these countries.

\section{Data and Methodology}

This paper uses the estimates of sectoral pollution intensities for industrial activities from the Industrial Pollution Projection System database (Hettige et al. 1995). The database includes fourteen different pollutant types, expressed in pounds of pollutant per million dollars of output at 1987 prices, with three-digit International Standard Industrial Classification (ISIC) disaggregation levels. The pollutants are categorized into four main groups. The TOXIC group includes toxic chemicals in the air, water, or soil. The BIO group includes bioaccumulative metals in the air, water, or soil. The AIR group includes air pollutants, such as nitrogen oxides, sulfhur oxides, volatile organic compounds, all suspended particulates, and carbon monoxide. The WATER group includes water pollutants, such as biological oxygen demand and total suspended solids.

The data set includes eighteen transition countries, eight of which concluded negotiations in December 2002 and became member-states

of the European Union as of May 2004. The manufacturing output of these countries is obtained from the Industrial Statistics Database 
(INDSTAT3 2005; United Nations Industrial Development Organization [UNIDO] 1996) at three-digit ISIC disaggregation levels. ${ }^{7}$ The observations for these countries, for fourteen pollutants over fourteen years, are unbalanced. Technology is assumed to be fixed according to 1987 U.S. technology levels across countries and in time. In other words, we assume that transition countries are all using the same technology as what U.S. industry was using in 1987, and there is no technological progress during the analyzed period. ${ }^{8}$

We calculated pollution intensities - that is, emissions - by multiplying the output in millions of U.S. dollars with pollution-intensity coefficients for each sector of each country from 1987 to 2000. Adding the pollution intensities for all sectors gave us the total pollution intensities in the manufacturing sectors for our panel, which is used to estimate the relation between the total pollution intensities and per capita GDP in the next section.

\section{Estimation and Results}

We start our analysis by estimating the relation between total pollution intensities $(E)$ and GDP per capita $(G D P K)$ for all transition countries and all pollutants with the following model:

$$
E_{i t}=\beta_{0}+\beta_{1} G D P K_{i t}+\beta_{2} G D P K_{i t}^{2}+\varepsilon_{i t},
$$

where $i$ is a country index, $t$ is a time index, and $\varepsilon_{i t}$ states the disturbance with zero mean and $\sigma^{2}$ variance. Because some exogenous factors may be omitted from the list of independent variables, or may be correlated with pollution intensities, we estimate the relation by both ordinary least squares (OLS) and generalized least squares (GLS). ${ }^{9}$ Table 1 reports the Lagrange multiplier (LM) test and the Hausman's $\chi^{2}$ specification test results. High LM test values favor GLS over OLS, and high values of Haussman's $\chi^{2}$ test favor fixed-effects models over random-effects models. The model is chosen by testing the orthogonality of the random effects and the regressors. The null hypothesis states no correlation. Thus, large values of the test suggest statistical preference for a fixed-effects model specification. ${ }^{10}$ Table 1 presents the estimates of fixed-effect, random-effect, and basic pooled regression models and test statistics. The signs of $\hat{\beta}_{1}$ and $\hat{\beta}_{2}$ are expected to be positive and negative, respectively. The turning points that give the maximum point of the inverse U-shaped curve for each pollutant, $-\hat{\beta}_{1} / 2 \hat{\beta}_{2}$, are of particular importance. 


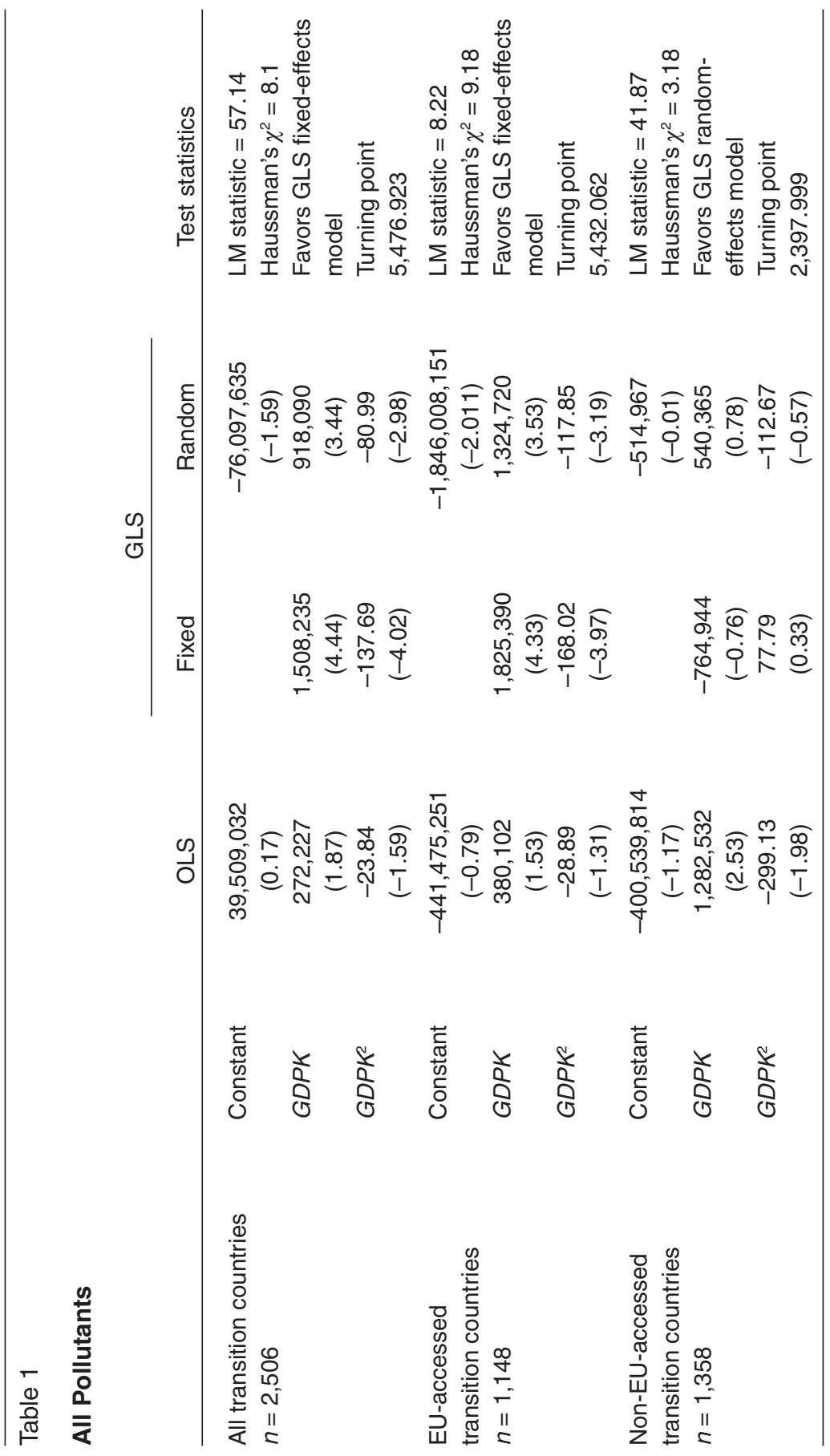


The results clearly indicate that there is an inverted U-shaped relation between pollution intensity and income per capita for all transition countries. According to fixed effects results, GDPK and $G D P K^{2}$ estimators are significantly different from zero and both have expected signs. The turning point is calculated as $\$ 5,710 .{ }^{11}$

\section{Differences Between the Two Groups of Transition Countries}

Our simple model suggests a concave pollution-income path that eventually slopes down. Does that mean that higher-income transition countries are enacting good environmental policies and have better-defined property rights? Are lower-income transition countries enacting bad policies, and would they be better off with international guidance in setting pollution standards? Can we explain the role of "better-defined" property rights on environmental quality by investigating the differences between the two samples? To find an answer, assuming EU membership requires better-defined property rights, we divide the sample between transition countries that became EU members as of May 1, 2004 (EUaccessed transition countries) and those that are not yet EU members (non-EU-accessed transition countries). ${ }^{12}$

The results are reported in the second and third rows of Table 1. Using the same estimation techniques as above, we find no statistically significant relation between pollution intensity and GDP per capita in non-EU-accessed transition countries. EU-accessed transition countries, however, show a significant inverted U-shaped relation between pollution intensity and GDP per capita, with $\$ 5,432$ as the turning point.

Because the GDP per capita for non-EU-accessed countries does not exceed $\$ 3,000$, the results are not surprising. However, it is doubtful that an observed inverted U-shaped pollution-income path for the full sample, and no path for poorer non-EU-accessed transition countries, is sufficient to argue that the policies of the poorer countries are inefficient, or that they do not have good pollution regulations.

\section{The Effects of Different Groups of Pollutants}

The literature recognizes that different pollutants lead to different results when testing for environmental Kuznets curves. Nevertheless, most studies managed to find inverse U-shaped patterns for most pollutants. ${ }^{13}$ 
We divide the sample across groups of pollutants (TOXIC, BIO, AIR, and WATER) to capture the differences among pollutants and reestimate the relationship. The water pollutants BOD and TSS show similar results to the full sample results. ${ }^{14}$ The rest of the pollutant groups do not present any significant relation between pollution intensities and GDP per capita. Table 2 contains water pollutant estimations and test results.

Narrowing the samples by grouping the pollutants, we find that BOD and TSS water pollutants are the only pollutants for EU-accessed transition countries that support such a relation. These results may suggest that EU-accessed transition countries adapted better-defined property rights to prevent water pollution. However, the results do not suggest the opposite for other types of pollution.

The analysis also suggests that EU-accessed transition country tests favor fixed-effects models, which in turn suggests that emission differences across countries can be captured by differences in the constant term. On the other hand, non-EU-accessed transition country tests favor the random-effects model, suggesting that screening emissions are randomly distributed across this group of countries.

Another interesting finding is that non-EU-accessed countries suggest a significant U-shaped relation between pollution intensities and GDP per capita for toxic chemicals in the air, water, or soil, suggesting a (minimum) turning point at $\$ 724$. The result suggests that the countries may have moved away from producing manufacturing goods that emit toxic chemicals in the air, water, and soil at very early stages of transition and started producing these goods at later stages. This result, again, does not necessarily suggest any environmental regulation changes in these countries.

\section{Composition Effects: EU Versus Non-EU Transition Countries}

Our analyses suggest that instead of examining the entire inverted U-shaped pollution-income path, we should investigate certain forms of pollution decline with economic growth for certain groups of countries over time, to understand the effect of better-defined property rights. The composition of economic activities and technology is an important factor for understanding the effect of property rights. Property rights may lead to changes in the composition of economic activities or technology, which 


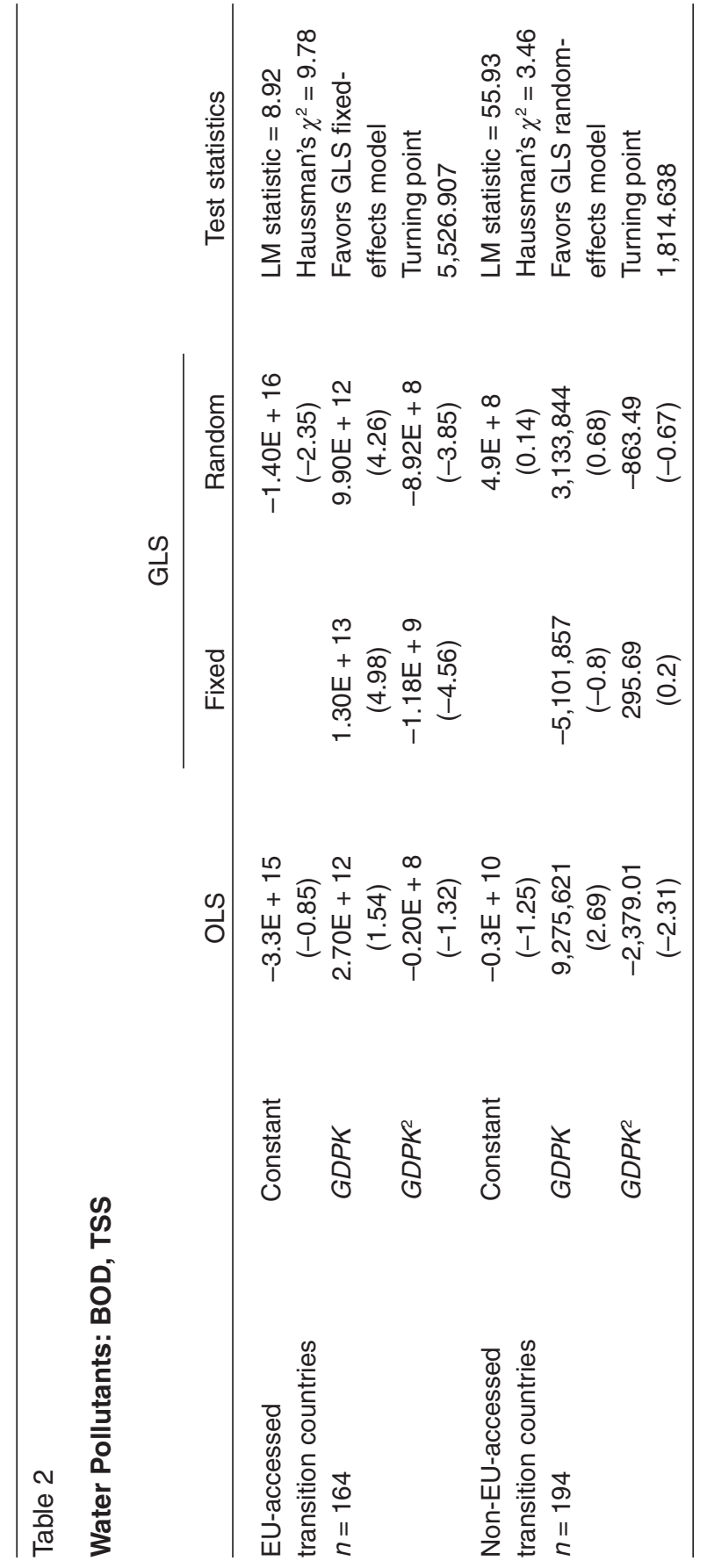


may result in downward pressure on emissions if sectors with low emission intensities grow faster than do sectors with high emission intensities. There is also a scale effect corresponding to the manufacturing share of total output. Manufacturing output substantially decreased early in transition for most countries, resulting in a decrease in total pollution (Vukina et al. 1999). However, industrial activity started growing rapidly in the later stages of transition in some of these countries. This does not necessarily cause total pollution to increase rapidly as well, if production moves toward cleaner sectors as captured by the composition effect. Therefore, the change in pollution intensities would depend on the dominating effect. If the (positive) scale effect dominates the (negative) composition effect, total pollution will continue increasing proportionally to increases in production. On the other hand, if the (negative) composition effect dominates the (positive) scale effect, total pollution will fall (Lucas et al. 1992; Vukina et al. 1999). ${ }^{15}$ We calculated these effects for eighteen transition countries for an unbalanced fourteen years; Table 3 presents the results. Positive (negative) scale effects present the increase (decrease) of pollution proportionally to the aggregate manufacturing activity. Positive composition effects indicate deterioration in environmental quality as composition changes toward dirtier manufacturing sectors. Negative composition effects indicate improvement in environmental quality, suggesting that manufacturing sectors with low-emission intensities grow faster than sectors with high-emission intensities.

Calculations show that the manufacturing share of total output in the EU-accessed transition countries (except Slovenia) increased during the examined period. Among the EU-accessed transition countries, Hungary, Czech Republic, and Slovakia present an obvious pattern for composition changes toward cleaner manufacturing sectors. Sectors with low-emission intensities in these countries show faster growth than do sectors with high-emission intensities in all types of pollutants. GDP per capita for these countries is around $\$ 5,000$. Interestingly, Slovenia behaves very differently than the other EU-accessed transition countries. Our calculations show that the manufacturing share of total output in Slovenia decreased during the examined period. However, this decrease did not lead to any composition changes away from dirtier sectors and toward cleaner sectors. More interestingly, GDP per capita for this country is about $\$ 11,500$, according to World Bank statistics.

Calculations for non-EU-accessed transition countries are not very surprising, because they suggest lower manufacturing share of total out- 



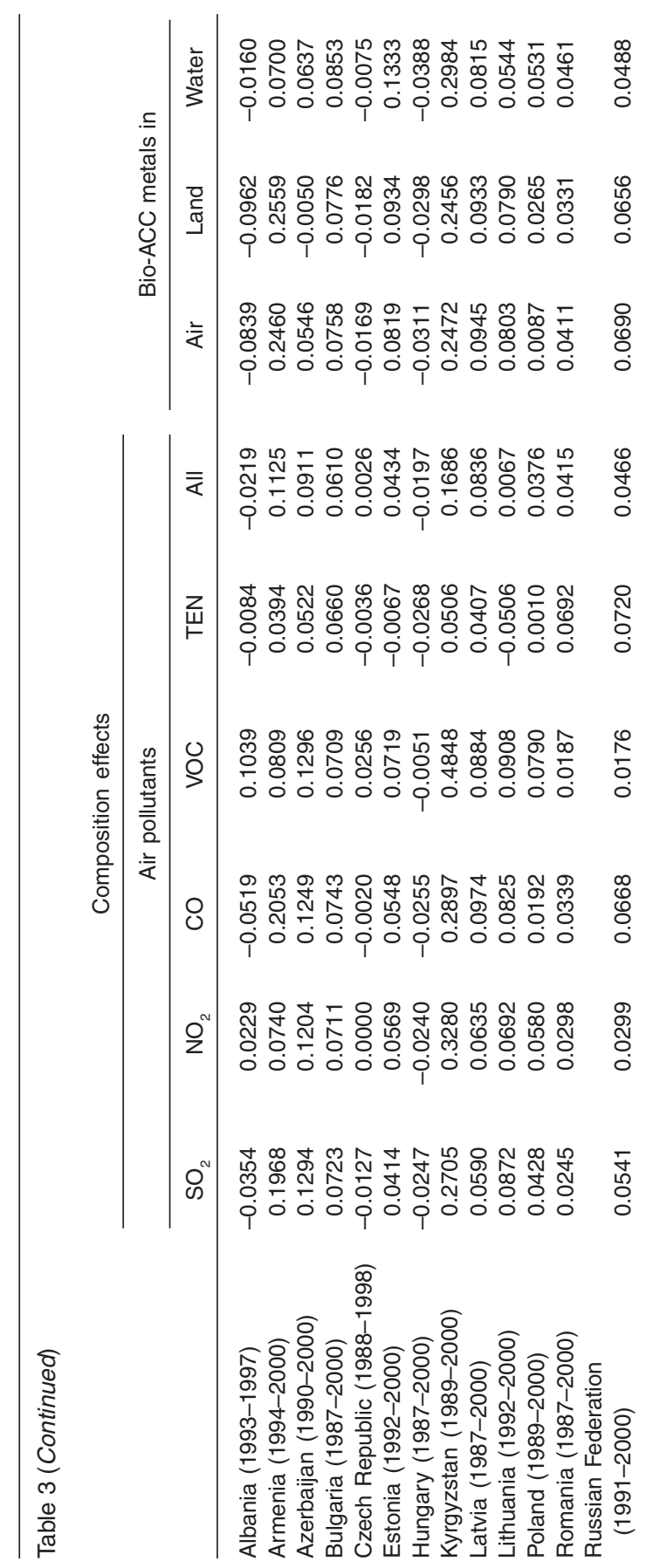




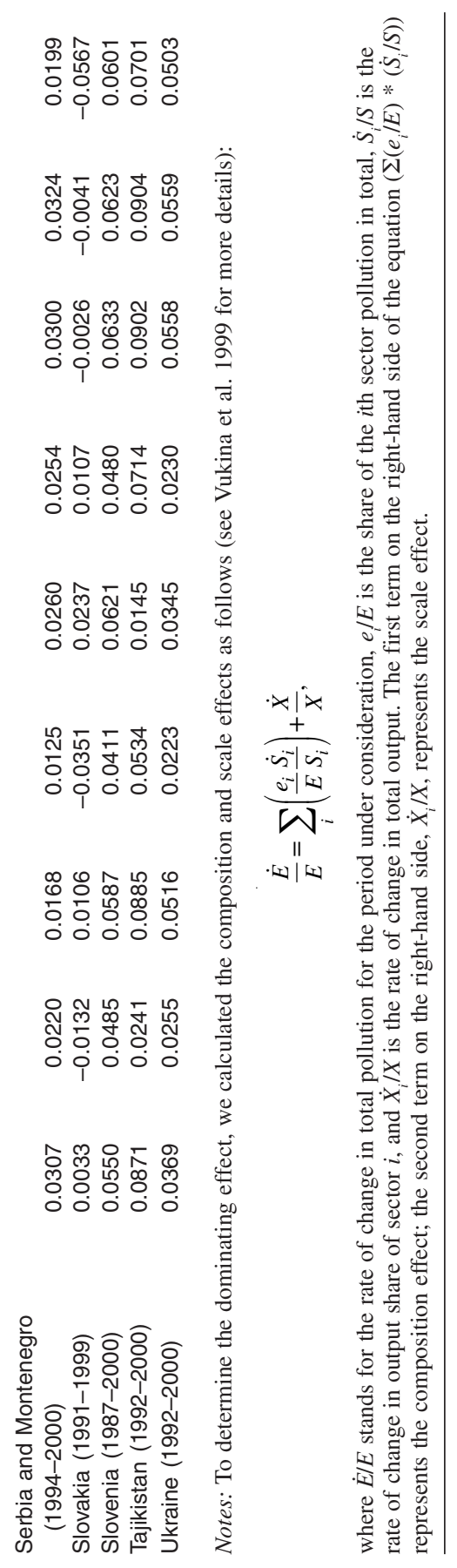


put for most of the countries and composition effects toward dirtier sectors. ${ }^{16}$ Overall, the results suggest that the sectors with composition changes toward cleaner sectors are mostly the sectors in EU-accessed transition countries that emit water and air pollutants into the environment. Among them, sectors in Czech Republic, Hungary, and Slovakia that emit bioaccumulative metals and toxic chemicals in air, land, and water show faster growth in low-emission intensities than high emission intensities.

\section{Conclusion}

This study investigated whether an inverted- $U$ relation exists between total pollution intensity in manufacturing output and income per capita for eighteen transition countries for an unbalanced fourteen years. The key part of this study was to capture the effect of differences in property rights on the relation by comparing two groups of transition countries. One group presented the new EU-member countries with better-established property rights, as a country must meet certain EU environmental standards to be a member state. The second group comprised the rest of the transition countries with poorly established property rights, because those countries have not yet established or prepared for such environmental standards. We recognize that not being a part of the European Union does not necessarily suggest that property rights are less defined in these countries. We tried to understand whether some transition countries would benefit from international guidance in setting pollution standards.

We found that in EU-accessed transition countries, only BOD and TSS water pollutants supported a relation between property rights and pollution. Non-EU-accessed transition countries did not support the relation at all. Environmental policy may be more ambitious in countries with higher incomes, which are the EU-member states in our sample. However, it may also be the effect of the EU standards and regulations. Because our findings suggested that EU-accessed transition countries may have adapted better-defined property rights to prevent only water pollution, the latter argument is obscure.

To understand the origins of change in emissions, we investigated the composition of economic activities as an important factor to understand the effect of property rights. This analysis provides a clearer insight to understand the relation between economic growth and pollution with indication of property rights. Our calculations showed that non-EU-accessed 
transition countries suggested decreases in manufacturing share of total output for most of the countries and composition effects toward dirtier sectors. On the other hand, though manufacturing share of total output in the EU-accessed transition countries (except Slovenia) increased during the examined period, composition effects suggested that sectors with low-emission intensities grow faster than do sectors with high-emission intensities, mostly in the sectors that emit water and air pollutants into the environment.

Among the EU-accessed transition countries, Hungary, Czech Republic, and Slovakia (with per capita GDPs of \$5,000) present an obvious pattern for composition changes of manufacturing toward cleaner sectors for all types of pollutants. Therefore, it might be very useful to investigate the environmental policies and regulations in these EU states as role models. Moreover, the EU countries may provide international cooperation, encouraging non-EU-accessed transition countries to reduce emissions and move toward cleaner manufacturing sectors while sustaining economic growth.

\section{Notes}

1. One group of transition countries, which induced reforms affecting openness, showed cleaner composition effect, whereas the other group of transition countries, which induced reforms of privatization and enterprise restructuring, showed dirtier composition effect.

2. Although these countries differ geographically and in environmental and socioeconomic conditions, they are similar in taking both economic efficiency and environmental sustainability into consideration.

3. Albania, Poland, Romania, and Slovenia showed positive growth in 1993, and twelve other transition countries showed positive growth in 1994. See Stern (1996) for more details.

4. See World Bank, EU-8 Quarterly Economic Report, April 2004. Also, increase in incomes may lead to more environmental pressure with increases in consumption, or environmental control may not be compatible with the market economy. The two reasons may not sufficiently ensure sustainable development.

5. Leblang (1996) argued that countries with well-defined property rights grow faster than do countries with poorly defined property rights, and that the nature of the political regime influences economic growth indirectly through the definition of property rights. Leblang (1996) tests the relations between property rights, democracy, and economic growth using panel data from 1960 to 1990 for many countries. Similarly, Scully (1992) argued that efficiency differences between economies are the result of differences in the efficiency of the property rights structure.

6. Barzel (1989) argued that if the full protection of rights is costly, then rights are never complete or well defined. However, if the ratio of benefits of property rights to their costs increases, then property rights will be defined better in a society. 
That is why it is not surprising that the property rights are, generally, poorly defined in developing countries and well defined in developed countries.

7. The latest data available for each cross section is for 2000. Because the negotiations are concluded in 2002, it would be better to have 2002 in the sample. However, the sample still captures the preparation and negotiation time period for these countries.

8. Technology allows countries to develop cleaner technologies that would substitute for dirtier technologies when producing any given commodity, which leads to decreases in pollution per unit of output when holding the output mix constant. Therefore, this assumption should be treated carefully. Vukina et al. (1999) make the same assumption and note that it leads to a pessimistic look on environmental quality.

9. Therefore, we estimated Equation (1) assuming the error term is the sum of two components: $\varepsilon_{i t}=c_{i}+u_{i t}$, where $c_{i}$ represents a country effect and $u_{i t}$ is the remaining error. It is assumed that the intercepts are drawn from a common distribution with mean $c$ and variance $\sigma_{c}^{2}$.

10. Fixed-effects estimation assumes that differences across countries can be captured by differences in the constant term, or, simply, by introducing a dummy variable for each country, which leads to large degrees of freedom loss. If we are confident that the differences between countries are just parametric shifts of the regression function (1), it will be appropriate to use fixed-effects models. If not, then it may be more appropriate to view individual specific constant terms as randomly distributed across cross-sectional units. Because there is no justification that omitted variables are not correlated with GDP per capita, the random-effects model may also give biased and inconsistent results.

11. Among many empirical papers on the environmental Kuznets curve, Grossman and Krueger (1995) find a peak before per capita GDP of \$8,000 when examining for $\mathrm{SO}_{2}$, TSP, and water for various countries and years. Some studies do not even find a peak within reasonable range of incomes (Kahn 1998; Selden and Song 1994). Most other studies agree that the findings are sensitive to countries and years in the sample, as well as functional forms and specifications (Harbaugh et al. 2002; Hilton and Levinson 1998; Roberts and Grimes 1997).

12. Member transition states are Czech Republic, Estonia, Hungary, Latvia, Lithuania, Poland, Slovakia, and Slovenia. Accession negotiations for Czech Republic, Estonia, Hungary, Poland, and Slovenia had started in March 1998, and in October 1999 for the rest. Transition countries that are not yet EU members are Albania, Armenia, Azerbaijan, Bulgaria, Kyrgyzstan, Romania, Russian Federation, Serbia and Montenegro, Tajikistan, and Ukraine. Bulgaria and Romania started negotiations in 1999 and are set for membership in 2007.

13. For example, $\mathrm{CO}_{2}$ shows a concave emission-income path with no peak at reasonable income levels (Holtz-Eakin and Selden 1995; Roberts and Grimes 1997) which may be because it is a global pollutant and difficult to regulate emissions. Indoor air pollution, on the other hand, may be internalized, and suggests an inverse U-shaped relation between income and indoor air quality (Chaudhuri and Pfaff 1998).

14. This finding is consistent with Shafik and Bandyopadhyay (1994), who find water and sanitation pollution peaks earlier.

15. There are also many other studies separating the environmental effect of trade liberalization into scale and composition effects (Grossman and Krueger 1993, 1995; Stern 1996). 
16. The only exception is Albania. However, this can be because of the short sample Albania presents.

\section{References}

Alston, L.J.; G.D. Libecap; and R. Schneider. 1996. "The Determinants and Impact of Property Rights: Land Titles on the Brazilian Frontier." Journal of Law, Economics and Organization 12, no. 1: 25-61.

Andreoni, J., and A. Levinson. 2001. "The Simple Analytics of the Environmental Kuznets Curve." Journal of Public Economics 80, no. 2: 269-286.

Arora, S., and T.N. Cason. 1999. "Do Community Characteristics Influence Environmental Outcomes? Evidence from the Toxics Release Inventory." Southern Economic Journal 65, no. 4: 691-716.

Barzel, Y. 1989. Economic Analysis of Property Rights. Cambridge: Cambridge University Press.

Chaudhuri, S., and A. Pfaff. 1998. "Household Income, Fuel Choice, and Indoor Air Quality: Microfoundations of an Environmental Kuznets Curve.” Working Paper, Economics Department, Columbia University, New York.

Deacon, R.T. 1994. "Deforestation and the Rule of Law in a Cross-Section of Countries." Land Economics 70, no. 4: 414-430.

Fidrmuc, J. 2003. "Economic Reform, Democracy and Growth During PostCommunist Transition." European Journal of Political Economy 19, no. 3: 583-604.

Frankel, J.A., and A.K. Rose. 2002. "Is Trade Good or Bad for the Environment? Sorting Out the Causality." National Bureau of Economic Research Working Paper 9201, Cambridge, MA.

Grossman, G.M., and A.B. Krueger. 1993. "Environmental Impact of a NAFTA.” In The U.S.-Mexico Free Trade Agreement, ed. P.M. Garber, pp. 13-56. Cambridge MA: MIT Press.

1995. "Economic Growth and the Environment." Quarterly Journal of Economics 110 , no. 2: 353-377.

Harbaugh, W.T.; A. Levinson; and D.M. Wilson. 2002. "Reexamining the Empirical Evidence for an Environmental Kuznets Curve." Review of Economics and Statistics 84, no. 3: 541-551.

Hettige, H.; P. Martin; M. Singh; and D. Wheeler. 1995. "IPPS: The Industrial Pollution Projection Project.” Policy Research Working Paper 1431, Washington DC, World Bank.

Hilton, F.G.H., and A. Levinson. 1998. "Factoring the Environmental Kuznets Curve: Evidence from Automative Lead Emissions." Journal of Environmental Economics and Management 35, no. 2: 126-141.

Holtz-Eakin, D., and T. Selden. 1995. "Stoking the Fires? $\mathrm{CO}_{2}$ Emissions and Economic Growth.” Journal of Public Economics 57, no. 1: 85-101.

Kahn, M. 1998. "A Household Level Environmental Kuznets Curve.” Economics Letters 59, no. 2: 269-273.

Leblang, D.A. 1996. "Property Rights, Democracy and Economic Growth.” Political Research Quarterly 49, no. 1: 5-26.

Lucas, R.E.B.; D. Wheeler; and H. Hettige. 1992. "Economic Development, Environmental Regulation and the International Migration of Toxic Industrial Pollu- 
tion: 1960-1988." In International Trade and the Environment, World Bank Discussion Papers, ed. P. Low, pp. 67-86. Washington, DC: World Bank.

Millimet, D.L., and T. Stengos. 1999. "A Semiparametric Approach to Modeling the Environmental Kuznets Curve Across U.S. States.” Southern Methodist University, Dallas, TX.

Pargal, S., and D. Wheeler. 1996. "Informal Regulation of Industrial Pollution in Developing Countries: Evidence from Indonesia.” Journal of Political Economy 104, no. 6: 1314-1327.

Roberts, J.T., and P.E. Grimes. 1997. "Carbon Intensity and Economic Development 1962-1991: A Brief Exploration of the Environmental Kuznets Curve." World Development 25, no. 2: 191-198.

Scully, G.W. 1992. Constitutional Environments and Economic Growth. Princeton: Princeton University Press.

Selden, T.M., and D. Song. 1994. "Environmental Quality and Development: Is There a Kuznets Curve for Air Pollution Emissions?" Journal of Environmental Economics and Management 27, no. 2: 147-162.

Shafik, N., and S. Bandyopadhyay. 1992. "Economic Growth and Environmental Quality: Time Series and Cross-Section Evidence.” Policy Research Working Paper no. WPS904, Washington, DC, World Bank.

Stern, N. 1996. "The Transition in Eastern Europe and the Former Soviet Union: Some Strategic Lessons from the Experience of 25 Countries over Six Years." European Bank for Reconstruction and Development Working Paper no. 18, London.

United Nations Industrial Development Organization (UNIDO). 1996. International Yearbook of Industrial Statistics, 1996. New York.

Vukina, T.; J.C. Beghin; and E.G. Solakoglu. 1999. "Transition to Markets and the Environment: Effects of the Change in the Composition of Manufacturing Output." Environment and Development Economics 4, no. 4: 582-598.

Wang, P.; A.K. Bohara; R.P. Berrens; and K. Gawande. 1998. "A Risk Based Environmental Kuznets Curve for U.S. Hazardous Waste Sites.” Applied Economics Letters 5, no. 12: 761-763.

To order reprints, call 1-800-352-2210; outside the United States, call 717-632-3535. 